\title{
Evaluation of saliva as a complementary technique to the diagnosis of COVID-19: a systematic review
}

\author{
Katherine Sagredo-Olivares ${ }^{1}$, Constanza Morales-Gómez ${ }^{1}$, Juan Aitken-Saavedra ${ }^{2,3,4}$ \\ ${ }^{1}$ Undergraduate, Faculty of Dentistry, University of Chile, Santiago, Chile \\ ${ }^{2}$ Department of Oral Pathology and Medicine, Faculty of Dentistry, University of Chile, Santiago, Chile \\ ${ }^{3}$ Graduate Program in Dentistry, School of Dentistry, Federal University of Pelotas, Pelotas, Brazil \\ ${ }^{4}$ Dental Service, San Camilo Hospital, San Felipe, Chile
}

Correspondence:

Postal address: 8380492

Olivos 943, Independencia, Santiago, Chile

jaitken@odontologia.uchile.cl

Received: $30 / 10 / 2020$ Accepted: 01/02/2021

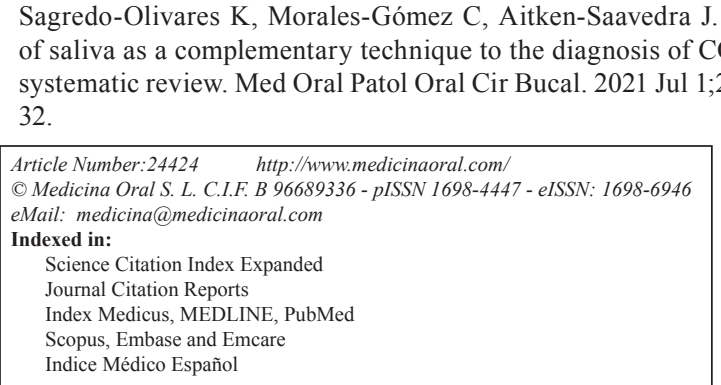

\begin{abstract}
Background: Infectious disease coronavirus 2019 (COVID-19) is caused by the SARS-CoV-2 virus, and it mainly affects the upper respiratory tract. The gold standard for its diagnosis is real-time reverse transcription polymerase chain reaction (RT-qPCR) performed on a nasopharyngeal swab. In contrast, testing saliva has significant advantages as a diagnostic method.

Material and Methods: We searched for articles evaluating saliva as a diagnostic method for COVID-19 on the PUBMED/MEDLINE, WEB OF SCIENCE, COCHRANE, and SCIELO platforms. We initially found 233 articles and 20 were selected for inclusion following the Preferred Reporting Items for Systematic Reviews and Meta-Analyses protocol: 18 cross-sectional studies and 2 case reports, including 8 from America, 8 from Asia, and 4 from Europe. The studies evaluated the presence of viral RNA, IgG, IgM, and IgA in samples of unstimulated saliva from adults with confirmed or suspected COVID-19. The vast majority of the studies performed RT-qPCR on the saliva samples and compared the results with the gold standard (a nasopharyngeal swab of the same patient). Results: Saliva samples analyzed by RT-qPCR, reverse transcription isothermal amplification (RT-LAMP), spectroscopy, and enzyme-linked immunosorbent assay (ELISA) offer high sensitivity to detect SARS-CoV-2 in the early stages of the disease and among asymptomatic patients as compared to nasopharyngeal swab RT-qPCR. In addition, the self-collection of saliva offers the possibility of receiving telemedicine instructions to carry out the test, reducing the risk of contagion.

Conclusions: The diagnosis of COVID-19 through saliva is sensitive, non-invasive, and is of low risk for the healthcare professionals. However, further studies are recommended to validate its clinical use.
\end{abstract}

Key words: Saliva, SARS-CoV, COVID19, Salivas. 


\section{Introduction}

Coronaviruses are a type of RNA virus that belong to the Coronoviridae family and that have been detected in humans and other animals. Infectious coronavirus diseases can cause severe acute respiratory syndrome coronavirus (SARS-CoV). In late 2019, in Wuhan, China, cases of pneumonia were identified that were caused by a virus initially called the 2019 novel coronavirus (2019-nCoV), but it was then renamed "severe acute respiratory syndrome coronavirus 2" (SARS-CoV-2). This virus rapidly spread worldwide (1). As of July 2020 , it is estimated that there had been a total of 17.6 million confirmed cases and 680 thousand deaths from COVID-19 worldwide (2). SARS-CoV-2 mainly affects the upper respiratory tract, and its most common symptoms include fever, cough, dyspnea, and myalgia. However, sputum production, headache, hemoptysis, and diarrhea have also been reported (1). As a result, patients diagnosed with coronavirus-19 (COVID-19) suffer from physical and psychological deterioration, affecting their health-related quality of life (3).

For the diagnosis of this disease, the gold standard applies reverse transcriptase polymerase chain reaction (RT-qPCR) to samples obtained using nasopharyngeal and oropharyngeal swabs (4). The specificity of this testing method appears to be high, but false-positive results have been detected due to swab contamination, especially in asymptomatic patients. The sensitivity of the technique is estimated to be around $66 \%-80 \%$ (4). Due to the progressive increase in positive cases, there is great interest in improving the SARS-CoV-2 diagnostic method, to achieve a greater specificity and sensitivity, and allowing for a larger number of infected people to be diagnosed more rapidly, including asymptomatic patients, since it has been reported that they also spread the virus (5). In addition, taking a nasopharyngeal swab causes discomfort and the possibility of bleeding for the patient, and a risk of contagion for health professionals collecting the sample. In this context, saliva could offer an alternative, since it has been shown to be useful for diagnosing different respiratory diseases, is easy to collect and store, and its collection is non-invasive (6). Because the SARS-CoV-2 infection mechanism begins with binding to the receptor for angiotensin-converting enzyme 2 (ACE2), which is widely expressed in the salivary glands, the virus is likely to be detectable in saliva $(7,8)$. The global SARS-CoV-2 pandemic has unleashed a global public health problem. The massive level of contagion and the large percentage of deaths that this virus has produced has prompted the research and development of new detection techniques. Therefore, the objective of this systematic review was to evaluate saliva as a diagnostic technique for COVID-19.

\section{Material and Methods}

- Protocols and sources of information
This systematic review was conducted according to the guidelines of the Cochrane Handbook for Systematic Reviews of Interventions, following the fourphase flow diagram of the Preferred Reporting Items for Systematic Reviews and Meta-Analyses Statement. This review is registered in the International Prospective Register of Systematic Reviews PROSPERO with the code: CRD42020209856. The literature search was carried out by two independent reviewers in July 2020. The following databases were screened: PubMed (National Library of Medicine), Cochrane (Elsevier), and Web of Science (Thomson Reuters). In addition, the reference lists of the selected articles were searched manually for additional articles. Articles published in English, Spanish, and Portuguese over the last 2 years were considered. The search strategy is described in Supplement 1. Two researchers used a predefined data collection form to independently extract and summarize the data from the included studies (K.A.S.O and C.B.M.G). The adjudicating senior author resolved any disagreements (J.P.A.S). The main outcome was an evaluation of saliva as a diagnostic fluid among people infected by COVID-19.

- Data extraction

We analyzed all studies reported in English, Portuguese or Spanish that met the inclusion criteria/PICO. We extracted information such as the authors' names, the country where the study was undertaken, the publication year, study type, factors reported, sample size, the sensitivity, and specificity of the salivary diagnostic methods (RT-qPCR, RT-LAMP, spectroscopy and enzyme-linked immunosorbent assay (ELISA) as compared to the gold standard method (RT-qPCR of a nasopharyngeal swab) and the percentage of positivity in the diagnosis of COVID-19 through salivary diagnosis. The authors used Review Manager software to synthesize the results according to the Cochrane Collaboration statistical guidelines. A random-effects model was used. Data were gathered in spreadsheets and divided into qualitative data and quantitative data. Qualitative data were synthesized through a narrative review. Due to the high degree of heterogeneity in terms of the different studies and methodologies, conducting a quantitative meta-analysis was considered inappropriate.

\section{Results}

A total of 233 references were identified in the 4 electronic databases. None were identified through other sources. After the removal of 53 duplicates and the use of a 5-year filter, 136 titles/abstracts were examined and 36 articles met the eligibility criteria and were included for full-text review. After a thorough reading of these articles and the exclusion of those that contained insufficient information, 20 articles were finally included for analysis (9-28). The flow chart of the study is presented in Fig. 1. 


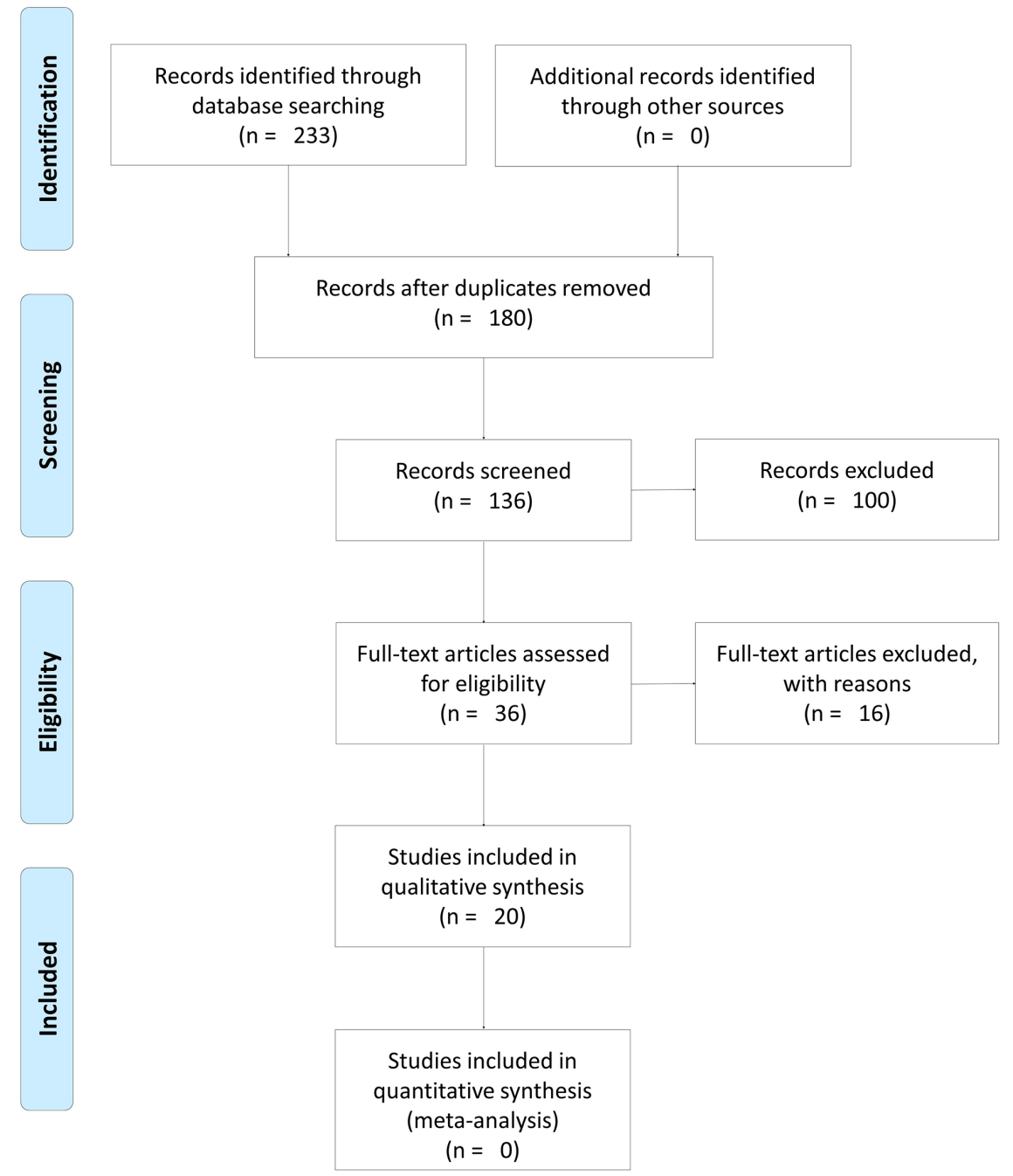

Fig. 1: Search flow according to the Prisma statement.

All articles were published in English in 2020. There were 17 cross-sectional studies, 2 case reports and 1 prospective study, including 8 studies from America, 8 from Asia, and 4 from Europe. Considering all 20 selected articles, a total of 2,355 patients were examined after obtaining diagnostic samples but only 1,557 patients from these 20 articles were characterized into subgroups before the examination. Within these non-additive subgroups, a total of 335 were confirmed (21.5\%) and 1177 were suspected (75.6\%) of having COVID-19, and within these 2 groups, 179 were categorized as symptomatic (11.5\%) and 112 as asymptomatic (7.2\%). Regarding the salivary sample collection method, 13 articles $(65 \%)$ used patient self-collection samples, 5 articles $(25 \%)$ had the sample collected by a professional, and in 2 articles (10\%) who collected the sample was not specified. In addition, 3 articles used profes- sional instruction through telemedicine to guide the self-collection of samples. Among the 20 select articles, 15 articles collected, in addition to saliva, a nasopharyngeal swab for a direct comparison, while the other 5 studies used the patient's initial diagnostic data as the diagnostic reference standard. Regarding the molecular biology diagnostic technique, one or more techniques were evaluated. Among the 20 selected articles, 18 articles processed the salivary sample by using RT-qPCR and 2 articles only used an immunoassay (ELISA, for example). Among the studies that performed RT-qPCR, four articles included in the methodology an extraction of viral RNA using the QIAamp Viral RNA Mini Kit (Qiagen). In addition, 9 articles compared RT-qPCR with other techniques such as RT-LAMP, ST, LFAbased RST, nCoV-DK, SMGNP, or HT-LAMP. These data are summarized in Table 1. 
Table 1: Characterization of the articles of the systematic review.

\begin{tabular}{|c|c|c|c|c|c|}
\hline Author & Study & Subjects & $\begin{array}{c}\text { Sam- } \\
\text { ple }\end{array}$ & Exams & Results \\
\hline $\begin{array}{l}\text { Azzi L, et } \\
\quad \text { al. } \\
\text { Italy (9). }\end{array}$ & $\mathrm{CS}$ & $\begin{array}{l}38 \text { confirmed subjects } \\
\text { (hospitalized) and } 81 \\
\text { suspected subjects (am- } \\
\text { bulatory) }\end{array}$ & $\begin{array}{l}\text { NSP } \\
\text { Saliva } \\
\text { S/C }\end{array}$ & $\begin{array}{l}\text { RST based on } \\
\text { LFA } \\
\text { rT-PCR }\end{array}$ & $\begin{array}{l}\text { The sensitivity of the RST was } 93 \% \text { while its speci- } \\
\text { ficity was } 42 \% \text {. There were no differences among } \\
\text { the asymptomatic and symptomatic individuals. }\end{array}$ \\
\hline $\begin{array}{l}\text { Azzi L, et } \\
\quad \text { al. } \\
\text { Italy (10). }\end{array}$ & CS & $\begin{array}{l}25 \text { confirmed subjects } \\
\text { (hospitalized) }\end{array}$ & $\begin{array}{l}\text { NSP } \\
\text { Saliva } \\
\text { B/P }\end{array}$ & $\begin{array}{l}\text { Qiagen rT- } \\
\quad \text { PCR }\end{array}$ & $\begin{array}{c}\text { SARS-CoV-2 was detected in all } 25 \text { patients' first } \\
\text { salivary swab. Two patients' respiratory swabs } \\
\text { showed negative results on the same day. }\end{array}$ \\
\hline $\begin{array}{l}\text { Azzi L, et } \\
\quad \text { al. } \\
\text { Italy (11). }\end{array}$ & CR & $\begin{array}{l}2 \text { confirmed subjects } \\
\text { (hospitalized) }\end{array}$ & $\begin{array}{l}\text { NSP } \\
\text { Saliva } \\
\text { B/P }\end{array}$ & $\begin{array}{l}\text { Qiagen rT- } \\
\quad \text { PCR }\end{array}$ & $\begin{array}{c}\text { In both patients, the results of the RT-qPCR were } \\
\text { positive in saliva even after } 26 \text { days, but the result of } \\
\text { the nasopharyngeal swab was negative. }\end{array}$ \\
\hline $\begin{array}{l}\text { Chau NVV, } \\
\text { et al. } \\
\text { Vietnam } \\
\text { (12). }\end{array}$ & PS & $\begin{array}{l}30 \text { confirmed (isolated): } \\
17 \text { symptomatic and } 13 \\
\text { asymptomatic subjects }\end{array}$ & $\begin{array}{l}\text { NSP } \\
\text { Saliva } \\
\text { B/P }\end{array}$ & rT-PCR & $\begin{array}{l}\text { Asymptomatic cases were mostly detected by RT- } \\
\text { qPCR in saliva rather than in nasopharyngeal swabs }\end{array}$ \\
\hline $\begin{array}{l}\text { Faustini SE, } \\
\text { et al. } \\
\text { UK (13). }\end{array}$ & $\mathrm{CS}$ & $\begin{array}{l}18 \text { confirmed subjects } \\
\text { (hospitalized), } 39 \text { symp- } \\
\text { tomatic subjects and } 6 \\
\text { asymptomatic subjects } \\
\text { (ambulatory) }\end{array}$ & $\begin{array}{l}\text { Blood } \\
\text { Saliva } \\
\text { B/P }\end{array}$ & ELISA & $\begin{array}{l}\text { ELISA can be modified to easily detect serum and } \\
\text { saliva antibody responses to severe, mild, and as- } \\
\text { ymptomatic COVID-19 infections. }\end{array}$ \\
\hline $\begin{array}{l}\text { Fukumoto T, } \\
\text { et al. } \\
\text { Japan (14). }\end{array}$ & $\mathrm{CS}$ & $\begin{array}{l}9 \text { confirmed subjects (no } \\
\text { mor information) }\end{array}$ & $\begin{array}{l}\text { NSP } \\
\text { Saliva } \\
\text { spu- } \\
\text { tum } \\
\text { N/S } \\
\end{array}$ & $\begin{array}{l}\text { rT-PCR } \\
\text { nCoV-DK }\end{array}$ & $\begin{array}{c}\mathrm{nCoV}-\mathrm{DK} \text { was found to be as effective as direct PCR } \\
\text { in detecting SARS-CoV-2 in all sample types. The } \\
\text { concordance rate was } 95.2 \% \text { for nasopharyngeal } \\
\text { swab samples, } 95.5 \% \text { for saliva samples }\end{array}$ \\
\hline $\begin{array}{l}\text { Guest JL, } \\
\text { et al. } \\
\text { USA (15). }\end{array}$ & CS & $\begin{array}{l}108 \text { suspected subjects } \\
\text { (symptomatic) and } 51 \\
\text { suspected subjects (as- } \\
\text { ymptomatic) }\end{array}$ & $\begin{array}{l}\text { NSP } \\
\text { Saliva } \\
\text { Blood } \\
\text { S/C } \\
\end{array}$ & $\begin{array}{l}\text { rT-PCR } \\
\text { ST }\end{array}$ & $\begin{array}{l}\text { Saliva samples collected by the participants were } \\
\text { found to be adequate and sufficient for detecting } \\
\text { SARS-CoV-2 RNA. }\end{array}$ \\
\hline $\begin{array}{l}\text { Iwasaki S, } \\
\quad \text { et al. } \\
\text { Japan (16). }\end{array}$ & $\mathrm{CS}$ & $\begin{array}{l}10 \text { confirmed subjects } \\
\text { and } 66 \text { suspected subjects }\end{array}$ & $\begin{array}{l}\text { NSP } \\
\text { Saliva } \\
\text { S/C }\end{array}$ & $\begin{array}{l}\text { Qiagen rT- } \\
\text { PCR }\end{array}$ & $\begin{array}{c}\text { Saliva samples taken within } 2 \text { weeks after the onset } \\
\text { of symptoms and in the convalescent phase showed } \\
\text { the viral load decreased earlier in saliva compared to } \\
\text { the nasopharyngeal samples. }\end{array}$ \\
\hline $\begin{array}{l}\text { Jamal AJ, } \\
\quad \text { et al. } \\
\text { Canada (17). }\end{array}$ & CS & $\begin{array}{l}91 \text { confirmed subjects } \\
\text { (hospitalized) }\end{array}$ & $\begin{array}{l}\text { NSP } \\
\text { Saliva } \\
\text { S/C }\end{array}$ & rT-PCR & $\begin{array}{l}\text { NSP was only } 6 \% \text { more sensitive than saliva pairs } \\
\text { collected in the first week of illness in this study. }\end{array}$ \\
\hline $\begin{array}{l}\text { Kai-Wang } \\
\text { To } \\
\text { et al. } \\
\text { China (18). }\end{array}$ & CS & $\begin{array}{l}12 \text { confirmed subjects } \\
\text { (hospitalized) }\end{array}$ & $\begin{array}{l}\text { Saliva } \\
\text { S/C }\end{array}$ & rT-PCR & $\begin{array}{l}\text { SARS-CoV-2 could be detected in the saliva speci- } \\
\text { mens of } 11 \text { of the } 12 \text { patients studied. }\end{array}$ \\
\hline $\begin{array}{l}\text { Lalli MA, } \\
\quad \text { et al. } \\
\text { USA (19). }\end{array}$ & $\mathrm{CS}$ & $\begin{array}{l}5 \text { confirmed subjects } \\
\text { (hospitalized) }\end{array}$ & $\begin{array}{l}\text { Saliva } \\
\text { S/C }\end{array}$ & $\begin{array}{l}\text { RT-LAMP } \\
\text { rT-PCR }\end{array}$ & $\begin{array}{l}\text { The pretreatment protocol without viral RNA } \\
\text { extraction in RT-LAMP significantly im- } \\
\text { proved the sensitivity of the examination and en- } \\
\text { abled rapid testing of asymptomatic subjects. }\end{array}$ \\
\hline $\begin{array}{l}\text { McCormick- } \\
\text { Baw C, et al. } \\
\text { USA }(20)\end{array}$ & $\mathrm{CS}$ & $\begin{array}{l}156 \text { subjects (no more } \\
\text { information) }\end{array}$ & $\begin{array}{l}\text { NSP } \\
\text { Saliva } \\
\text { B/P }\end{array}$ & rT-PCR & $\begin{array}{c}\text { 47/49 samples were positive in saliva compared } \\
\text { to NPS and 105/106 were negative, resulting in a } \\
\text { percentage of positive agreement of } 96 \% \text { and } 99 \% \text {, } \\
\text { respectively. }\end{array}$ \\
\hline $\begin{array}{l}\text { Nagura-Ike- } \\
\text { da M, et al. } \\
\text { Japan (21). }\end{array}$ & $\mathrm{CS}$ & $\begin{array}{l}103 \text { confirmed subjects: } \\
15 \text { symptomatic and } 88 \\
\text { asymptomatic subjects. }\end{array}$ & $\begin{array}{l}\text { NSP } \\
\text { Saliva } \\
\text { S/C }\end{array}$ & $\begin{array}{l}\text { Qiagen rT- } \\
\text { PCR } \\
\text { RT-LAMP }\end{array}$ & $\begin{array}{c}\text { Viral RNA in saliva was detected at significantly } \\
\text { higher percentages in specimens collected within } 9 \\
\text { days of symptom onset. }\end{array}$ \\
\hline $\begin{array}{c}\text { Pasomsub E, } \\
\text { et al. } \\
\text { Thailand } \\
\text { (22). }\end{array}$ & CS & $\begin{array}{l}200 \text { symptomatic suspi- } \\
\text { cious (ambulatory) sub- } \\
\text { jects }\end{array}$ & $\begin{array}{l}\text { NSP } \\
\text { Saliva } \\
\text { S/C }\end{array}$ & RT-qPCR & $\begin{array}{l}\text { RT-qPCR tests of saliva demonstrated high sensitiv- } \\
\text { ity and performance comparable to the current stan- } \\
\text { dard nasopharyngeal swab. }\end{array}$ \\
\hline
\end{tabular}


Table 1 cont.: Characterization of the articles of the systematic review.

\begin{tabular}{|c|c|c|c|c|c|}
\hline $\begin{array}{l}\text { Randad PR, } \\
\quad \text { et al. } \\
\text { USA (23). }\end{array}$ & CS & $\begin{array}{l}321 \text { confirmed (hospital- } \\
\text { ized), confirmed recov- } \\
\text { ered and suspect subjects }\end{array}$ & $\begin{array}{l}\text { Saliva } \\
\text { Blood } \\
\text { S/C }\end{array}$ & $\begin{array}{c}\text { Multiplex } \\
\text { magnetic } \\
\text { microparticle } \\
\text { ("bead")- } \\
\text { based SARS- } \\
\text { CoV-2 saliva } \\
\text { immunoassay }\end{array}$ & $\begin{array}{c}\text { SARS-CoV-2 appears to trigger a humoral immune } \\
\text { response that results in an almost simultaneous } \\
\text { increase in } \operatorname{IgG}, \operatorname{IgM} \text {, and IgA } \\
\text { levels in both serum and saliva }\end{array}$ \\
\hline $\begin{array}{l}\text { Sullivan PS, } \\
\text { et al. } \\
\text { USA (24). }\end{array}$ & $\mathrm{CS}$ & $\begin{array}{l}159 \text { subjects (no more } \\
\text { information) }\end{array}$ & $\begin{array}{l}\text { NSP } \\
\text { Saliva } \\
\text { Blood } \\
\text { S/C }\end{array}$ & $\begin{array}{l}\text { RT-PCR } \\
\text { ST }\end{array}$ & $\begin{array}{c}\text { Viral RNA, IgG, IgA, and IgM were detected in } \\
\text { saliva. }\end{array}$ \\
\hline $\begin{array}{l}\text { Tajima Y, } \\
\quad \text { et al. } \\
\text { Japan (25). }\end{array}$ & CR & 1 confirmed subject & $\begin{array}{l}\text { NSP } \\
\text { Saliva } \\
\text { S/C }\end{array}$ & $\begin{array}{l}\text { SMGNP } \\
\text { rT-PCR }\end{array}$ & $\begin{array}{c}\text { The virus can be detected in saliva for } 37 \text { days after } \\
\text { onset, even after the patient becomes asymptomatic } \\
\text { by SMGNP. }\end{array}$ \\
\hline $\begin{array}{l}\text { Valentine- } \\
\text { Graves, M. } \\
\text { et al. } \\
\text { USA (26). }\end{array}$ & $\mathrm{CS}$ & $\begin{array}{l}153 \text { subjects (no more } \\
\text { information) }\end{array}$ & $\begin{array}{l}\text { NSP } \\
\text { Saliva } \\
\text { Blood } \\
\text { S/C }\end{array}$ & $\begin{array}{l}\text { PCR } \\
\text { ST }\end{array}$ & $\begin{array}{l}\text { Self-collection of diagnostic samples at home dur- } \\
\text { ing telemedicine care allows people to be tested for } \\
\text { SARS-CoV-2 infection while self-isolating. }\end{array}$ \\
\hline $\begin{array}{l}\text { Wei S, et al. } \\
\text { USA (27). }\end{array}$ & $\mathrm{CS}$ & $\begin{array}{l}149 \text { suspected subjects } \\
\text { (ambulatory) }\end{array}$ & $\begin{array}{c}\text { Saliva } \\
\text { N/S }\end{array}$ & $\begin{array}{l}\text { HP-LAMP } \\
\text { rT-PCR }\end{array}$ & $\begin{array}{c}\text { HP-LAMP enables rapid detection of SARS-CoV-2 } \\
\text { directly from saliva in } 30 \text { minutes (sensitivity } 97 \% \\
\text { and specificity } 100 \% \text { ). }\end{array}$ \\
\hline $\begin{array}{l}\text { Williams E, } \\
\text { et al. } \\
\text { Australia } \\
\text { (28). }\end{array}$ & $\mathrm{CS}$ & 522 suspected subjects & $\begin{array}{l}\text { NSP } \\
\text { Saliva } \\
\text { S/C }\end{array}$ & rT-PCR & $\begin{array}{c}\text { 39/522 suspected patients had PCR-positive NPS } \\
\text { and } 33 / 39 \text { confirmed patients }(84.6 \% \text {, sensibility) } \\
\text { had SARS-CoV-2 detected in their saliva. }\end{array}$ \\
\hline
\end{tabular}

CS, cross-sectional study; CR, Case report; PS, Prospective study; S/C, Self-collection; B/P, By professionals; N/S, No specific; RST, Rapid Salivary Test; LFA, Lateral flow technique, rT-PCR, Reverse transcription polymerase chain reaction; Qiagen, QIAamp Viral RNA Mini Kit, ELISA, Enzyme-Linked ImmunoSorbent Assay; nCoV-DK, Rapid Detection Kit; ST, Serological tests; RT-LAMP, Reverse Transcription Loop-mediated isothermal Amplification; SMGNP, sugar chain immobilized gold nanoparticles; HP-LAMP, High-Performance Loop-mediated isothermal Amplification.

\section{Discussion}

Due to the need to optimize the diagnostic method to achieve a high specificity and sensitivity and to allow a greater number of infected people to be diagnosed more rapidly, this review compiled information that evaluated saliva as an alternative testing sample for the diagnosis of COVID-19. Reviewing the geographical distribution of the selected studies, we can observe that there was an equality between the number of cases globally and the number of publications per continent, being America (17.3 million), Asia (7.6 million), and Europe (6.4 million) among the locations with the largest number of confirmed cases around the world (2). It is interesting to note that the selected articles came from countries with a high level of scientific production, such as the United States, Japan, and China.

Regarding the method of collecting the samples, the articles all pointed out the self-collection of saliva as an efficient technique, being easy to collect, non-invasive, and with very little risk of contagion among healthcare professionals (19). In contrast to saliva, the nasopharyngeal swab technique can be uncomfortable, in addition to presenting a risk of bleeding in patients with thrombocytopenia (25). In some studies, they also collected blood and saliva samples, where equivalent immunoglobulin levels could be observed, and they concluded that saliva could be a tool to evaluate short and longterm humoral immunity in COVID-19 infections, and for understanding the nature of the natural and vaccineinduced responses to this disease $(13,22)$. It is interesting to mention that within the selected studies, three articles instructed their patients through telemedicine to perform a self-collection of samples from their homes, a methodology that, considering the current context and the importance of social distancing, reinforces the relevance of its use and implementation $(15,23,26)$.

Among the selected studies, RT-qPCR was the most widely used test to diagnose COVID-19 in saliva. This test demonstrated a sensitivity of $84.2 \%$ and a specificity of $98.9 \%$ compared to the nasopharyngeal swab RT-qPCR results. In addition, a 97.5\% concordance rate was recorded between both samples (22). Furthermore, some articles used Qiagen to extract the viral RNA from saliva samples $(10,11,16,21)$, and they found the RT-qPCR was positive for up to 26 days after the onset of symptoms (11). Other articles evaluated the saliva by means of LAMP, demonstrating that it is a technique that allows for the rapid and sensitive detection of 
SARS-CoV-2, offering the possibility of easily evaluating the results by colorimetry $(19,21)$. Furthermore, Wei et al. observed that with HP-LAMP, positive results can be obtained from saliva in just 30 minutes, observing a sensitivity and specificity of $97 \%$ and $100 \%$, respectively (27). One study showed that $\mathrm{nCoV}-\mathrm{DK}$ is able to effectively detect SARS-CoV-2 in saliva, comparing it to PCR of a nasopharyngeal swab. In addition, it was observed that the detection time could be reduced by half, since the purification and extraction steps of viral RNA are not necessary (14). Also, IgG, IgM, and IgA antibodies were detected in saliva samples by immunoassays in people with severe, mild, and asymptomatic COVID-19 infections, demonstrating that these tests could serve to evaluate short-term and long-term humoral immunity $(13,23,24)$. It is of great importance to highlight that most of the articles mentioned the need to detect asymptomatic people with contagion capacity to control the spread of the pandemic. For this reason, it is urgent to find a diagnostic method that is faster, but just as sensitive and specific, as the gold standard (4). This is why some studies mention that saliva plays an important role in detecting the virus and, through efficient diagnostic tests, the spread of SARS-CoV-2 by asymptomatic patients could be prevented $(10-13,19,25)$. However, other studies affirm that in the samples of asymptomatic patients or convalescent patients, the sensitivity of the tests decreases (21) or is still unknown (22).

Science has focused efforts in recent years to search for and evaluate the effectiveness of salivary biomarkers that can be used to assess the presence, developmental risk and responses to therapies of some diseases (29). In this sense, saliva can play an important role in the transmission of COVID-19 infection, and it also allows for a convenient and non-invasive method of diagnosis (30). The fact that saliva can be used as an alternative to serum for the detection of organic biomarkers is due to the fact that the vast majority of proteins present in the serum are also expressed in saliva (31). It has been indicated that IgG in saliva, for example, may be a useful surrogate marker of this antibody status in serum (32). The COVID-19 virus in the saliva could come from the salivary glands through the ducts or gingival fluid or simply through secretions from the lower and upper respiratory tracts that combine with the saliva (30). Because the SARS-Cov2 infection mechanism begins with binding to the angiotensin-converting enzyme receptor 2 (ACE2), which is widely expressed in the salivary glands, in addition to allowing the detection of the virus in saliva $(7,8)$, stresses the diagnostic role of this fluid in the early stages (33) and it would therefore be of great use in detecting asymptomatic infected patients. Also, it was demonstrated the presence of spike viral protein in salivary glands, reinforcing the theory of saliva as tool to diagnose COVID-19 (34).
Within the limitations of this systematic revision, we can mention that not all of the articles described their patients epidemiologically, which, although it may not be decisive for the purposes of our study, because the virus has been distributed homogeneously in the worldwide population, this could introduce a bias due to differences of viral behavior in saliva due to the age or sex of those infected. What, according to our criteria, corresponds to a true limitation, is that some articles did not report whether the evaluated patients were confirmed or suspected cases, if they only suffered from symptoms, or if they were hospitalized. We believe that characterizing the patients participating in these studies is of vital importance in order to have prior knowledge of the percentage of confirmed patients and to establish the sensitivity and specificity of the diagnostic technique that is being evaluated. Furthermore, not all studies compared their salivary virus detection techniques with the gold standard. This point is essential to evaluate their efficiency as a diagnostic method and for potential follow-up of infected patients. Another limitation is that some studies used saliva samples self-collected by the patients, not specifying whether they were instructed in detail as to how to perform the procedure, so it is not really known if these samples were taken correctly or if the amount collected was sufficient to perform the analysis. Finally, the selected studies used different diagnostic salivary testing methodologies, so they cannot be compared with each other, making it difficult to fully evaluate the literature.

Despite the indicated limitations, this innovative systematic review offers an overview of saliva and its potential role as a source of biological biomarkers that may be useful for diagnosing or monitoring patients infected with SARS-CoV-2, especially considering the many advantages offered by this fluid. Considering the worldwide disorder caused by this virus and the need to detect infected patients, especially asymptomatic patients who could be unknowingly spreading the virus, the alternative of salivary collection, which could be carried out by the patient, reducing the risk of contagion in health care, proved to be sufficiently specific and sensitive (28) to be used in the general population. In addition, techniques such as immunoassays applied to saliva would allow for greater epidemiological control by being able to detect various sources of infection at the same time. Although the evaluated studies offer promising results, additional evidence is needed to confirm the efficacy of saliva as a sample fluid for diagnosing COVID-19. It is important to note that not only saliva could be useful as a complementary method in the diagnosis of COVID-19. SARS$\mathrm{COV}-2$ infection can cause oral manifestations (as oral vesiculobullous lesions) $(35,36)$, highlighting the role of dental surgeons in the diagnostic process. 


\section{References}

1. Song SH, Chen TL, Deng LP, Zhang YX, Mo PZ, Gao SC, et al. Clinical characteristics of four cancer patients with SARS-CoV-2 infection in Wuhan, China. Infect Dis Poverty. 2020;9:82.

2. Hemmer CJ, Geerdes-Fenge HF, Reisinger EC. COVID-19: Epidemiologische und klinische Fakten [COVID-19: epidemiology and clinical facts]. Radiologe. 2020;60:893-8.

3. Chen KY, Li T, Gong FH, Zhang JS, Li XK. Predictors of HealthRelated Quality of Life and Influencing Factors for COVID-19 Patients, a Follow-Up at One Month. Front Psychiatry. 2020;11:668.

4. Pascarella G, Strumia A, Piliego C, Bruno F, Del Buono R, Costa F, et al. COVID-19 diagnosis and management: a comprehensive review. J Intern Med. 2020;288:192-206.

5. Lotfi M, Hamblin MR, Rezaei N. COVID-19: Transmission, prevention, and potential therapeutic opportunities. Clin Chim Acta. 2020;508:254-66.

6. Zhang CZ, Cheng XQ, Li JY, Zhang P, Yi P, Xu X, et al. Saliva in the diagnosis of diseases. Int J Oral Sci. 2016;8:133-7.

7. Xu H, Zhong L, Deng J, Peng J, Dan H, Zeng X, et al. High expression of ACE2 receptor of $2019-\mathrm{nCoV}$ on the epithelial cells of oral mucosa. Int J Oral Sci. 2020;12:8.

8. Song J, Li Y, Huang X, Chen Z, Li Y, Liu C, et al. Systematic analysis of ACE2 and TMPRSS2 expression in salivary glands reveals underlying transmission mechanism caused by SARS-CoV-2. J Med Virol. 2020;92:2556-66.

9. Azzi L, Baj A, Alberio T, Lualdi M, Veronesi G, Carcano G, et al. Rapid Salivary Test suitable for a mass screening program to detect SARS-CoV-2: A diagnostic accuracy study. J Infect. 2020;81:e75-8. 10. Azzi L, Carcano G, Gianfagna F, Grossi P, Gasperina DD, Genoni A, et al. Saliva is a reliable tool to detect SARS-CoV-2. J Infect. 2020;81:e45-50.

11. Azzi L, Carcano G, Dalla Gasperina D, Sessa F, Maurino V, Baj A. Two cases of COVID-19 with positive salivary and negative pharyngeal or respiratory swabs at hospital discharge: A rising concern. Oral Dis. 2020:10.1111/odi.13368.

12. Chau NVV, Thanh Lam V, Thanh Dung N, Yen LM, Minh NNQ, Hung LM, et al. The natural history and transmission potential of asymptomatic SARS-CoV-2 infection. Clin Infect Dis. 2020;71:2679-87. 13. Faustini SE, Jossi SE, Perez-Toledo M, Shields A, Allen JD, Watanabe Y, et al. Detection of antibodies to the SARS-CoV-2 spike glycoprotein in both serum and saliva enhances detection of infection. medRxiv. 2020:2020.06.16.20133025.

14. Fukumoto T, Iwasaki S, Fujisawa S, Hayasaka K, Sato K, Oguri $\mathrm{S}$, et al. Efficacy of a novel SARS-CoV-2 detection kit without RNA extraction and purification. Int J Infect Dis. 2020;98:16-7.

15. Guest JL, Sullivan PS, Valentine-Graves M, Valencia R, Adam E, Luisi N, et al. Suitability and Sufficiency of Telehealth Clinician-Observed, Participant-Collected Samples for SARS-CoV-2 Testing: The iCollect Cohort Pilot Study. JMIR Public Health Surveill. 2020;6:e19731. 16. Iwasaki S, Fujisawa S, Nakakubo S, Kamada K, Yamashita Y, Fukumoto T, et al. Comparison of SARS-CoV-2 detection in nasopharyngeal swab and saliva. J Infect. $202 ; 81: e 145-7$.

17. Jamal AJ, Mozafarihashjin M, Coomes E, Powis J, Li AX, Paterson A, et al. Sensitivity of nasopharyngeal swabs and saliva for the detection of severe acute respiratory syndrome coronavirus 2 (SARS-CoV-2). Clin Infect Dis. 2020:ciaa848.

18. Lalli MA, Langmade SJ, Chen X, Fronick CC, Sawyer CS, Burcea LC, et al. Rapid and extraction-free detection of SARS-CoV-2 from saliva with colorimetric LAMP. medRxiv. 2020; hvaa267.

19. McCormick-Baw C, Morgan K, Gaffney D, Cazares Y, Jaworski $\mathrm{K}$, Byrd A, et al. Saliva as an Alternate Specimen Source for Detection of SARS-CoV-2 in Symptomatic Patients Using Cepheid Xpert Xpress SARS-CoV-2. J Clin Microbiol. 2020;58:e01109-20.

20. Nagura-Ikeda M, Imai K, Tabata S, Miyoshi K, Murahara N, Mizuno T, et al. Clinical Evaluation of Self-Collected Saliva by Quantitative Reverse Transcription-PCR (RT-qPCR), Direct RTqPCR, Reverse Transcription-Loop-Mediated Isothermal Amplification, and a Rapid Antigen Test To Diagnose COVID-19. J Clin Microbiol. 2020;58:e1438-20.

21. Pasomsub E, Watcharananan SP, Boonyawat K, Janchompoo P,
Wongtabtim G, Suksuwan W, et al. Saliva sample as a non-invasive specimen for the diagnosis of coronavirus disease 2019: a cross-sectional study. Clin Microbiol Infect. 2020:S1198-743X(20)30278-0. 22. Randad PR, Pisanic N, Kruczynski K, Manabe YC, Thomas D, Pekosz A, et al. COVID-19 serology at population scale: SARS-CoV-2-specific antibody responses in saliva. medRxiv. 2020:2020.05.24.20112300.

23. Sullivan PS, Sailey C, Guest JL, Guarner J, Kelley C, Siegler AJ, et al. Detection of SARS-CoV-2 RNA and Antibodies in Diverse Samples: Protocol to Validate the Sufficiency of Provider-Observed, Home-Collected Blood, Saliva, and Oropharyngeal Samples. JMIR Public Health Surveill. 2020;6:e19054.

24. Tajima Y, Suda Y, Yano K. A case report of SARS-CoV-2 confirmed in saliva specimens up to 37 days after onset: Proposal of saliva specimens for COVID-19 diagnosis and virus monitoring. J Infect Chemother. 2020;26:1086-9.

25. To KK, Tsang OT, Yip CC, Chan KH, Wu TC, Chan JM, et al. Consistent Detection of 2019 Novel Coronavirus in Saliva. Clin Infect Dis. 2020;71:841-3.

26. Valentine-Graves M, Hall E, Guest J, Adam E, Valencia R, Hardee I, et al. At-home self-collection of saliva, oropharyngeal swabs and dried blood spots for SARS-CoV-2 diagnosis and serology: postcollection acceptability of specimen collection process and patient confidence in specimens. PLoS One. 2020;15:e0236775.

27. Wei S, Kohl E, Djandji A, Morgan S, Whittier S, Mansukhani M, et al. Field-deployable, rapid diagnostic testing of saliva samples for SARS-CoV-2. medRxiv. 2020:2020.06.13.20129841.

28. Williams E, Bond K, Zhang B, Putland M, Williamson DA. Saliva as a Noninvasive Specimen for Detection of SARS-CoV-2. J Clin Microbiol. 2020;58:e00776-20.

29. Schafer CA, Schafer JJ, Yakob M, Lima P, Camargo P, Wong DT. Saliva diagnostics: utilizing oral fluids to determine health status. Monogr Oral Sci. 2014;24:88-98.

30. Vinayachandran D, Balasubramanian S. Salivary diagnostics in COVID-19: Future research implications. J Dent Sci. 2020;15:364-6. 31. Pineda-Martínez S, Hernández-Islas JL, Escobedo-Torres MP, Paredes-Alonzo IE, López-Candiani C, Correa D, et al. Immunoglobulin Concentrations in Plasma and Saliva During the Neonatal Period. Pediatr Neonatol. 2016;57:213-8.

32. Heaney JLJ, Phillips AC, Carroll D, Drayson MT. The utility of saliva for the assessment of anti-pneumococcal antibodies: investigation of saliva as a marker of antibody status in serum. Biomarkers. 2018;23:115-22.

33. Sabino-Silva R, Jardim ACG, Siqueira WL. Coronavirus COVID-19 impacts to dentistry and potential salivary diagnosis. Clin Oral Investig. 2020;24:1619-21.

34. Soares CD, Mosqueda-Taylor A, de Carvalho MGF, de Almeida OP. Oral vesiculobullous lesions as an early sign of COVID-19: immunohistochemical detection of SARS-CoV-2 spike protein. Br J Dermatol. 2020;10.1111/bjd.19569.

35. Martín Carreras-Presas C, Amaro Sánchez J, López-Sánchez AF, Jané-Salas E, Somacarrera Pérez ML. Oral vesiculobullous lesions associated with SARS-CoV-2 infection. Oral Dis. 2020;10.1111/ odi.13382.

36. Soares CD, Carvalho RA, Carvalho KA, Carvalho MG, Almeida OP. Letter to Editor: Oral lesions in a patient with Covid-19. Med Oral Patol Oral Cir Bucal. 2020;25:e563-4.

\section{Funding}

None declared.

\section{Conflict of interest}

None declared.

\section{Authors contributions}

J.A.S. designed the study, also being responsible for all stages of development of this research, from the acquisition and analysis of data and critical review of the manuscript. K.S.O. and C.M.G. were the responsible for guiding and participating in all stages of this study, design, interpretation of results and writing of the manuscript. 